\title{
Sustainable Development of Industrial Enterprises Based on Ecologization
}

\author{
Valery V. Lepikhin \\ Tatyana L. Lepikhina \\ Svetlana V. Litvinova
}

Perm National Research Polytechnic University, Russian Federation

Email: I-pstu@inbox.ru

\section{Doi:10.5901/mjss.2015.v6n3s5p119}

\begin{abstract}
Economic system sustainability could be reached only in definite (or optimal) combination of social reproduction proportions and rational utilization of natural resources. For modern economies of all levels such model of development could be qualified as sustainable. The article is devoted to the sustainable development of Perm Krai industrial enterprises. Definitions of "sustainable development of enterprise" with regard to the definition of "enterprise's sustainable development" concept are systematized in the issue. Efficient combination of the enterprise's economic, environmental and social subsystems is considered to be actually sustainable development. Correlation analysis of economic indicators' dependence on environmental and social parameters has been done in order to determine the factors strongly influencing the results of the enterprise's activity. It has been drawn a conclusion about the necessity of developing integral indicator including the assessment results of the enterprise's economic, environmental and social subsystems functioning.
\end{abstract}

Keywords: sustainable development, socio-economic subsystems, evolutionary approach, industrial enterprises

\section{Introduction}

The problem of "sustainable development" is one of the most urgent problems in the world. Interconnection of economic development and environmental worsening is obvious. So, there exists the demand for reasonable combination of profit maximization interests, material welfare and environmental requirements. This problem is touched upon in many international legal acts such as Stockholm Declaration of the United Nations Conference on the Human Environment (1972), Rio Declaration on Environment and Development (1992), "Agenda 21" (1992), Johannesburg Declaration on Sustainable Development (2002), UNEP Report "Towards "Green" Economies: a Way to Sustainable Development and Elimination of Poverty" (UNEP, 2011) and others.

"Agenda 21" contains an appeal to the U.N.O member-countries for development, adoption and further guaranteeing of coordination of national strategies in sustainable development. The foundation for these strategies should become "different sector economic, social and environmental programs and plans realized in the country" (Agenda XXI: Adopted by UNO Conference on Environment and Development, 1992). Therefore the task of transition to sustainable development on the state level and on the subjects' levels is actualized.

In modern conditions, most of the developed and developing countries choose the way following the concept of sustainable development. Sustainable development is the way based on the support of the long-run extended reproduction of productive potential, human resources and natural environment. Sustainable development ensures equilibrium of three associated elements of the system: economic, social spheres and environment (Ivanov, 2011).

Sustainable development implies the development based on three components of national economy: economic, social and environmental. And if until recently we could imagine the process of social development in two-dimensional coordinate system in which only social and economic parameters were taken into account and nature was considered to be beyond the limits of the managed system, now it is used three dimensional coordinate system including in addition environmental (natural resources) subsystem. International Union for protection of nature determines sustainable type of development as development which ensures real people's life quality improvement and at the same time preserves natural variety of the Earth (Vasikova, 2011).

Formation of new social reproduction structure in which environmental component, environmental approach to product reproduction depends on balanced development of three subsystems mentioned above. The role of Man in 
solving the problem of environmental quality conservation is great. The aim of the article is to study the formation of strong institutional, informational base for development of ecological production including rational utilization of conditions, resources and factors for making products and facilities without damaging environmental qualitative properties necessary for vital activity, as well as ecological reproduction in which production, distribution, exchange and consumption are realized at peace with nature.

\section{Literature Review}

We have tried to systematize approaches to definition of "sustainable development of enterprise" with regard to the definition of "enterprise's sustainable development" concept (table 1).

Table 1. Systematization of approaches to the definition of 'sustainable development of enterprise' concept

\begin{tabular}{|c|}
\hline Conservative approach \\
\hline $\begin{array}{l}\text { Such progressive qualitative change in the organization's activity which does not undermine the foundations of future enterprise } \\
\text { development (Bardasova et al., 2012, p.192) }\end{array}$ \\
\hline System approach \\
\hline $\begin{array}{l}\text { The process of changes reflecting the ability of the enterprise's economical activity system to meet the society requirements for a long } \\
\text { period of time, to promote its economic efficiency, to keep the well-being of the environment and resource base both now and in future } \\
\text { counteracting negative influence of external and internal factors (Koryakov, 2012) }\end{array}$ \\
\hline $\begin{array}{l}\text { The ability of the system of the enterprise's interconnected elements to provide viability and its economic efficiency growth taking into } \\
\text { account different environmental factors effect (Mikitas, 2013, p.10) }\end{array}$ \\
\hline Functioning as integral system keeping self-sufficiency irrespective of external factors change (Pechatkina \& Menshikova, 2011, p.138) \\
\hline $\begin{array}{l}\text { Such a state when none of structural components is being in period of transition or, in other words, when all structural components } \\
\text { function persistently (Terentyev, 2005, p.9) }\end{array}$ \\
\hline The result of activity of an enterprise at the limited resources utilization not disturbing environmental balance (Shubina, 2011, p.10) \\
\hline $\begin{array}{l}\text { Such a way of its functioning which is provided by transformation of internal environment of enterprise with the aim of self-preservation } \\
\text { and reproduction of social-economic processes by harmonization of interrelation with external environment (Khomyachenkova, 2011, p.8) }\end{array}$ \\
\hline Evolutional approach \\
\hline $\begin{array}{l}\text { Development of all subsystems of enterprise under internal and external factors when the wealth of owners in real terms does not change } \\
\text { for the worse in long-term outlook (Shestakov, 2009, p.9) }\end{array}$ \\
\hline $\begin{array}{l}\text { The state of harmony and controlled process of changes in which the scale of resources exploitation, the size and purposefulness of } \\
\text { investment, technological improvement and institutional change conform to the present and future demands. } \\
\text { Continuous process of enterprise's economy adjustment in accordance with market requirements which is expressed in securing } \\
\text { competitive ability on the base of innovative potential increase (Kolosova, 2011, p.13). }\end{array}$ \\
\hline $\begin{array}{l}\text { Controlled process of potential growth at the expense of economic balance support, motivation of employees' creative potential and } \\
\text { competitive ability increase, and due to these facts - ensuring of gradual rise in living standards of employees (shareholders). } \\
\text { Qualitative change of the system's elements, ties, and modes of its functioning (Biryukov, 2006, p.10) }\end{array}$ \\
\hline $\begin{array}{l}\text { Stable social-economic balanced development, not damaging natural environment and ensuring continuous progress of business entity } \\
\text { taking into consideration the prospects of stable position, growth of demand and enterprises and industrial sector economic efficiency } \\
\text { (Damaev, 2005, p.8) }\end{array}$ \\
\hline $\begin{array}{l}\text { Power of economic system to move to the target keeping financial sustainability, stable position in the market, resources balance and } \\
\text { ability to develop innovations in conditions of injurious effect of internal and external factors (Zinger, 2010, p.7) }\end{array}$ \\
\hline
\end{tabular}

On the basis of the given definitions' analysis it may be concluded that due to conservative approach any enterprise should develop now so that to guarantee stable foundation for the future development. System approach presupposes that fundamental principles of sustainable development are both the function of conservation and the function of reproduction as well as care of the available resources with the aim of self-preservation of enterprise as a system considering internal and external factors.

Followers of evolutional approach think that sustainable development promotes both self-preservation and reproduction of enterprise as a system and its continuous progress and rise of employees' living standard, i.e. balanced environmental-friendly social-economic development.

In opinion of Melnik (2005, p.654), "sustainable development" word combination carries definite inconsistency as far as "sustainability" means firmness which is characterized by constancy whereas "development" is the notion which is reflected in dynamics and has the sign of variability in progressive or regressive directions. So, it is necessary to mention that the nature of sustainable development correspond such development of social-environmental-economic system the characteristic feature of which is exclusively positive dynamics of the system's indicators in steady state (Melnik, 2005).

In this article we will rely on the definition proposed by Damaev (2005) in which sustainable development is 
understood as stable social-economic balanced development not damaging nature environment and ensuring continuous progress of business entity, taking into consideration the prospects of stable position, growth of demand and enterprises and industrial sector economic efficiency.

\section{Research Methodology}

Economic system sustainability could be reached only in definite (or optimal) combination of social reproduction proportions and rational utilization of natural resources. For modern economies of all levels such model of development could be qualified as sustainable.

There are many definitions of enterprise's sustainable development in the works of modern researchers. In the modern economic science there are about 100 of them. Moreover, this category is considered from different standpoints of theoretical and methodological approaches. As it is truly mentioned by Petrushinova (2014), conservative approach to sustainable development is oriented first of all to conservation of available resources with the aim to pass them to future generations. The main goal of system approach is the reproduction of available resources. While in developmental approach sustainable development implicates the fact, that global changes occurring in environment makes amendments which in their turn influence the trajectory of society development in whole (Petrushinova, 2014).

One of the main factors of sustainable development concept is the unity of three components: economic, social and environmental. And it is necessary to consider that only environmental priorities of development and conformity of economic goals to social and environmental interests makes possible to achieve stability.

Worsening of the situation connected with recourse depletion and environmental pollution cause the necessity of natural constituent activation. Orientation to considerable quantitative criteria of economic growth has lead to the sharp increase of consumption capacity. And this fact has become the reason for ecosystem overloading. Meanwhile ecosystem functioning is the necessary condition for normal vital activity of human society. Its breakdown can result in the modern economy collapse.

On the one hand considerable scientific and technical potential of mankind enlarges the economic advancement power, while on the other hand it is followed by negative environmental effect. Changing natural environmental processes anthropogenic activity threatens human health and life.

We can tell that crises is building up in the modern world and its overcoming is complicated by the lack of its estimation and the absence of any information about it as well as by declarative nature of sustainable economic development concept realization. Control of economic players' environmental activity requires the revision of conceptual framework of economic management on micro-, meso- and macro levels.

It is the awareness of necessity for guaranteed satisfaction of both economic and environmental needs which has lead to elaboration of sustainable development strategy. It is obvious that this process is possible only in case of ensuring environment resources base stable reproduction. So, in the first place it is necessary to consider the economic effect on the environment while estimating degree of development sustainability.

Resolution of environment-economic conflict influences formation of new social reproduction structure in which environmental component and environmental approach to product reproduction appear to be of the first priority. Human role in conservation policy is great. It concerns the formation of strong institutional, organizational, informational basis for environment-friendly production including rational use of conditions, resources and factors for making products and services not disturbing environment qualitative properties necessary for vital activity, and environment-friendly reproduction in which production, distribution, exchange and consumption is carried out in the harmony with nature.

Duality and bipolarity of economic system development define the intensification of conflict between environment and economy. This conflict appears between environmental measures of economical activity and economic growth in the process of natural resources utilization. This conflict shows the difference of private and social interests concerning nature management and character of production activity environmental effect. However, the most likely will be the variant of economic development in which environmental aspects of production activity are of special importance for society. Along with the appearance of ecological paradigm of economic activity it is conditioned the necessity of development of environmental and economic needs and interests of market players.

Thus, the main goals of environmental measures are the following ones:

1) Optimization of human activity conditions due to conservation and improvement of natural environment;

2) Changeover of production to non-polluting and closed cycles of resource-saving;

3) Rational utilization of natural resources providing their conservation, restoration and extended reproduction;

4) Protection and conservation of flora and fauna gene pool.

In accordance with requirements of sustainability economy has to ensure both material well-being and the most 
complete satisfaction of social and environmental human needs in long-term outlook. It implies balanced reproduction of national capital including physical, natural and human capitals (Derevyago, 2012).

The problem of sustainable development strategy is presented in literature by several approaches.

Thus, the theory of weak sustainability presupposes full interchangeability of natural, human and physical capitals. According to this concept, it is admitted attrition of the first one if it is compensated by appropriate increase of the second and the third elements. And it is scientific-technological progress that plays the main role in environmental-economic problems.

However, interchangeability of natural and of all the other forms of capital is in fact possible over a limited range. A number of elements of natural potential fulfill the basic functions of human life support and cannot be changed by anything. The more limited they are the more obvious this fact. And, as it is known, the possibility to perform its functions by this or that system is firstly determined by the elements which are the most restricted comparing to the level of needs, or critical elements. Due to the scope and character of nature management at the present stage natural capital is considered to be the critical element in the system of economic relations. So, the ability of sustainable development depends to a large extent on its utilization and reproduction.

Another concept according to which natural and physical capitals are not interchangeable was called the concept of strong sustainability. It implies binding natural reproduction of ecosystems (ecosystem capital). Moreover this concept assumes the balance between economic development principle and the laws of biosphere functioning. Therefore, strong mathematical approach to the estimation of development sustainability can be hardly applied. The authors of the work "Limits of Growth: 30 years later" think that many most important parameters and dependencies cannot be mathematically estimated. Unpredictability of environmental-economic systems' behavior increases because of human ability to choose and change the aims of activity. And any serious crises in real world results in groundlessness of many important assumptions on the base of which we made the model (Meadows \& Randers, 2005).

Environmental-economic interests and needs determine environmental behavior of entity which stimulates the development of social production preserving applicable for life environment. The problem is that specific conditions ensured by governmental and municipal economic incentives for environmental activity of market players are necessary for sufficient formation of such needs, interests and behavior.

In the modern environmental policy of Russian Federation there are marked two directions connected with each other: firstly, the arrangements aimed at stopping further environmental pollution with simultaneous ensuring of high economic growth of the country; secondly, arrangements necessary for gradual reduction of pollution and other negative effects made by already operating entities.

Environmental measures correspond with the process of successive introduction of intentions aimed at nature conservation and environmental sustainability in the spheres of legislation, management, development of technologies, in the economic and educational spheres, etc. This process means not only the introduction of resource saving technologies, waste treatment systems, the principle of "who is contaminating - pays". It means the consciousness of our planet, environmental space and natural biota finiteness as well as of existence of the natural environment anthropogenic deformation limit followed by ecological catastrophe and appearance of individual survival problem (Lukyanchikov \& Potravny, 2011).

It is important to study these measures as far as traditions and laws of macro economy emerged in the period when common influence of human activity on the environment did not exceed the boundaries of self-recovery potential of ecological system. Now the situation has changed. Anthropogenic load has increased the limit of natural complexes' sustainability and ecosphere in whole with respect to many parameters. Economic growth determined by supply and obtrusive stimulation of demand for secondary objects of consumption has lead to the damage for natural basis of life support and possibility to meet primary human needs. Mankind has reached the most important mark in its history which requires both the change of demographic situation and replacement of economy paradigm, namely its structure and way of functioning. Transition to the new stage of material culture is essential, the culture which is compatible and balanced with already fallen into decline natural potential of the planet. Further traditional economic development is hampered by two strong restrictions (Derevyago, 2008): a) limited ability of environment to accept and assimilate waste products; $b$ ) finite character of unrenewable natural resources.

It is believed that new strategy has no alternative: environmental requirements should come first whereas quantitative production level remains lower. Then the possibility to increase qualitative level appears. And environmental measures as the component of industrial economics are an indispensable condition of this strategy.

Ecologization of economy is the most important demand of the modern times. It implicates more diversified and at the same time systematic approach to the environment, awareness of nature's role in human life. Environmental measures are an indispensable condition and simultaneously the main constituent part of ecological progress. In fact, 
they mean ecological reliability of social and economic structure and development.

\section{Findings and Discussion}

We will consider the state of Perm Krai industrial enterprises illustrated by the indicators characterizing the functioning of three main subsystems: economical, social and ecological.

To determine the factors strongly influencing the result of industrial enterprises operation we will make correlation analysis of financial performance dependence (from profits to taxing) on some ecological and social indicators. Primarily we will examine the influence of ecological factors:

1) Atmospheric pollutant emissions from stationary sources (tons) (Table 2)

Table 2. Coefficient of correlation between atmospheric emissions and profits of Perm Krai industrial enterprises

\begin{tabular}{lc}
\hline Financial performance (pre-tax profit) in actual price, mln. rub. & Atmospheric pollution emissions from stationary sources (tons) \\
\hline Total in manufacturing an extracting industries, including: & -0.541 \\
\hline Mining operations & 0.881 \\
\hline Manufacturing activity & -0.436 \\
\hline
\end{tabular}

2) Electric energy consumption (mln of kilowatt hours) (Table 3)

Table 3. Coefficient of correlation between electric energy consumption and profits of Perm Krai industrial enterprises

\begin{tabular}{lc}
\hline Financial performance (pre-tax profit) in actual price, mln. rubles & Electric energy consumption (mln. kilowatt hours) \\
\hline Total in manufacturing and extracting industries, including & 0.044 \\
\hline Mining operations & 0.916 \\
\hline Manufacturing activity & -0.261 \\
\hline
\end{tabular}

\section{3) Restoration assignments (Table 4)}

Table 4. Coefficient of correlation between restoration assignments and profits of Perm Krai industrial enterprises

\begin{tabular}{lc}
\hline Financial performance (pre-tax profit) in actual price, mln. rub. & Restoration assignments \\
\hline Total in manufacturing and extracting industries, including & -0.457 \\
\hline Mining operations & -0.881 \\
\hline Manufacturing activity & 0.292 \\
\hline
\end{tabular}

In extractive industry strong dependence is observed between atmospheric pollution emissions and financial performance, between electric energy consumption and financial performance, between restoration assignments and profit (negative dependence) in mining operations also (Tables 2-4, Figures 1-3).

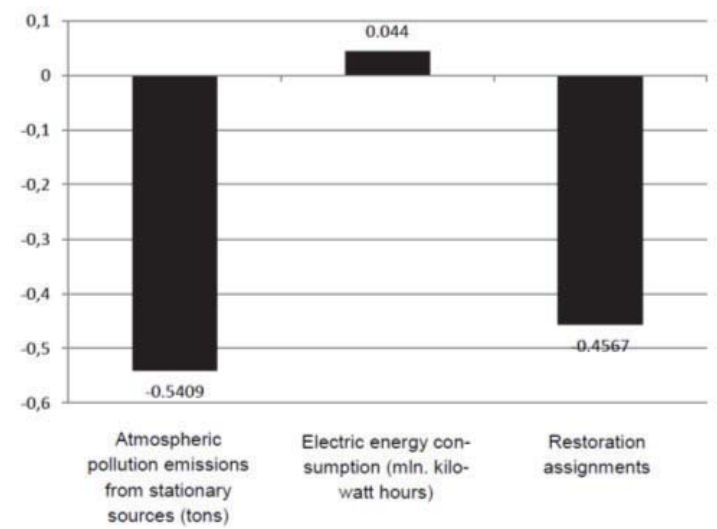

Figure 1. Coefficients of correlation between financial performance and ecological factors in manufacturing and extractive industries 


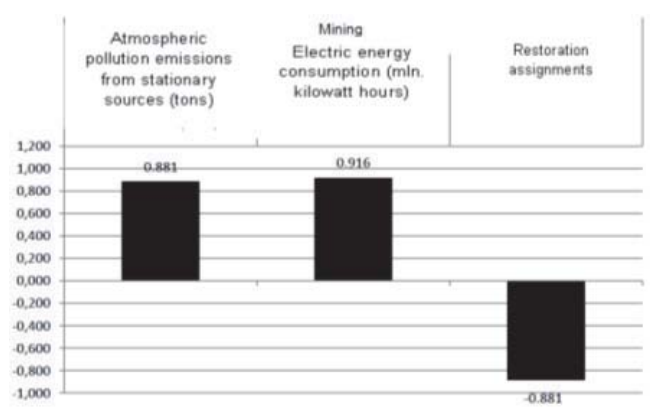

Figure 2. Coefficients of correlation between financial performance and ecological factors in extractive industry

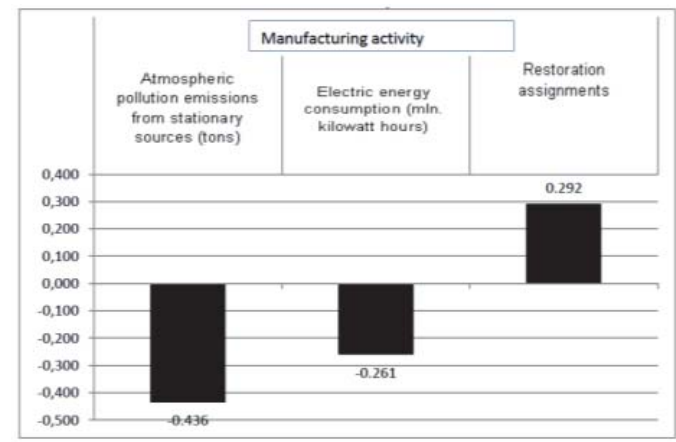

Figure 3. Coefficients of correlation between financial performance and ecological factors in manufacturing industry

So, it is worth considering three ecological factors in the integral index, namely those which cover extractive industry:

4) Atmospheric pollution emissions from stationary sources (tons)

5) Electric energy consumption

6) Restoration assignments.

Now let's examine influence of ecological factors $n$ financial performance:

7) Funds used up for labour protection arrangements (thousand rubles) (Table 5).

Table 5. Coefficient of correlation between funds used up for labour protection arrangements and profits of Perm Krai industrial enterprises

\begin{tabular}{lc}
\hline Financial performance (pre-tax profit) in actual price, mln. rubles & Funds used up for labour protection arrangements (thousand rubles) \\
\hline $\begin{array}{l}\text { Total in manufacturing and extractive industries, } \\
\text { including: }\end{array}$ & 0.3076 \\
\hline Mining operations & -0.6253 \\
\hline Manufacturing activity & 0.0737 \\
\hline
\end{tabular}

8) The number of persons with occupational disease identified for the first time (Table 6)

Table 6. Coefficient of correlation between the number of persons with occupational disease identified for the first time and profits of Perm Krai industrial enterprises

\begin{tabular}{|lc|}
\hline $\begin{array}{l}\text { Financial performance (pre-tax profit) in actual price, } \mathrm{mln} . \\
\text { rubles }\end{array}$ & $\begin{array}{c}\text { A number of persons with occupational disease identified for the } \\
\text { first time }\end{array}$ \\
\hline Total in manufacturing and extractive industries, including: & -0.2702 \\
\hline Mining operations & 0.3300 \\
\hline Manufacturing activity & 0.3349 \\
\hline
\end{tabular}


9) The number of victims' disability man-days for the period of 1 working day and more according to the medical certificate (Table 7)

Table 7. Coefficient of correlation between the number of disability persons and profits of perm Krai industrial enterprises

\begin{tabular}{lc}
\hline $\begin{array}{l}\text { Financial performance (pre-tax profit) in actual price, mln. } \\
\text { rubles }\end{array}$ & $\begin{array}{c}\text { A number of victims' disability man-days for the period of } 1 \\
\text { working day and more according to medical certificate }\end{array}$ \\
\hline Total in manufacturing and extractive industries, including: & -0.5155 \\
\hline Mining operations & 0.0171 \\
\hline Manufacturing activity & -0.1286 \\
\hline
\end{tabular}

10) The number of industrial accidents' victims with disability for 1 or more working days (Table 8)

Table 8. Coefficient of correlation between the number of industrial accidents' victims with disability for 1or more working days and profits of Perm Krai industrial enterprises

\begin{tabular}{lc}
\hline $\begin{array}{l}\text { Financial performance (pre-tax profit) in actual price, mln. } \\
\text { rubles }\end{array}$ & $\begin{array}{c}\text { The number of industrial accidents' victims with disability for } 1 \text { or more } \\
\text { working days }\end{array}$ \\
\hline $\begin{array}{l}\text { Total in manufacturing and extractive industries, } \\
\text { including: }\end{array}$ & -0.743 \\
\hline Mining operations & -0.447 \\
\hline Manufacturing activity & -0.465 \\
\hline
\end{tabular}

11) Average monthly basic calculated salary of workers in accordance with the economic activity (rubles) (Table 9)

Table 9. Coefficient of correlation between average monthly basic calculated salary and profits of Perm Krai industrial enterprises

\begin{tabular}{lc}
\hline $\begin{array}{l}\text { Financial performance (pre-tax profit) in actual price, mln. } \\
\text { rubles }\end{array}$ & $\begin{array}{c}\text { Average monthly basic calculated salary of workers in } \\
\text { accordance with economic activity (ruble) }\end{array}$ \\
\hline $\begin{array}{l}\text { Total in manufacturing and extractive industries, } \\
\text { including: }\end{array}$ & 0.856 \\
\hline Mining operations & 0.876 \\
\hline Manufacturing activity & 0.752 \\
\hline
\end{tabular}

Strong dependence is demonstrated between:

- Funds used up for labour protection arrangements in extractive industry (negative dependence) and financial performance;

- The number of victims of industrial accidents in whole and financial performance;

- Average monthly basic calculated salary and financial performance of industry in whole and severally in extractive and manufacturing industries.

\section{Concluding Remarks}

Thereby, the following social factors are worth considering in integral index: funds used up for labor protection arrangements (thousand rubles) in extractive industries; the number of industrial accidents' victims with disability for 1 or more days in all branches of industry; average monthly basic calculated salary of workers in accordance with their economic activity (rubles) in all branches of industry and severally in extractive and manufacturing industries.

The analysis carried out and presented in this article makes possible to conclude that indicators characterizing the functioning of Perm Krai economic, environmental and social subsystems influence sustainability of the regional system in whole. We think that generalized indicator characterizing sustainable development both of definite industrial enterprise and regional economy can play the role of a certain integral index. Such index including the most important characteristics of economic, environmental and social subsystems can serve as a criterion for assessment of economic sustainability level. 


\section{References}

Agenda XXI: Adopted by UNO Conference on Environment and Development, Rio-de-Janeiro, June 3-14 1992. [Online] Available: http://www.un.org/ru/documents/decl_conv/conventions/agenda21.shtml. (February 12, 2015).

Bardasova, E.V., Zotov, M.A., \& Ponikarova, A.S. (2012). Management of enterprise personnel potential development as the instrument of obtaining sustainable development in innovative economy. Bulletin of Kazan Technological University, 1 (15), $192-198$.

Biryukov, S.E. (2006). Formation of mechanisms for industrial enterprise sustainable development. PhD thesis: 08.00.05. Vladimir.

Damaev, D.V. (2005). Complex assessment of industrial enterprises' sustainable development: technical approach. PhD thesis: 08.00.05. Novosibirsk.

Declaration of the United Nations Conference on the Human Environment: Adopted by UNO Conference on the Human Environment, Stockholm, June 5-16, 1972. [Online] Available: http://www.un.org/ru/documents/decl_conv/declarations/declarathenv.shtml. (February 21, 2015).

Derevyago, I.P. (2008). Formation of the model for region's ecologically sustainable development. Regional economy: theory and practice, 24(81), $28-35$.

Derevyago, I.P. (2012). Economical foundations of environmental risk management. Minsk: BSTU.

Ivanov, V.A. (2011). Methodological foundations for sustainable development of regional social-environmental-economic systems. Bulletin of Research centre for corporative law, management and venture investment of Syktyvkar state university, 2. [Online] Available: http://koet.syktsu.ru. (December 4, 2014).

Johannesburg Declaration on Sustainable Development: Adopted by World Summit on Sustainable Development, Johannesburg, August 26 - September 4 2002. [Online] Available: http://www.un.org/ru/documents/decl_conv/declarations/decl_wssd.shtml. (February 19, 2015).

Khomyachenkova, N.A. (2011). Mechanism of integral assessment of industrial enterprises' sustainable development. PhD thesis: 08.00.05. Moscow.

Kolosova, T.V. (2011). Ensuring of enterprise sustainable development on the base of its innovative potential growth: Dr. thesis: 08.00.05. Nizhny Novgorod.

Koryakov, A.G. (2012). Management of industrial enterprise sustainable development: theory, methodology, practice. Dr. thesis: 08.00.05. Moscow.

Lukyanchikov, N.N., \& Potravny, I.M. (2011). Economy and organization of nature management. Moscow: UNITI-DANA.

Meadows, D., \& Randers, J. (2005). Limits to Growth: The 30-year Update. Chelsea Green Publishing Co.

Melnik, L.G. (2005). Foundations of sustainable development: teaching aid. Sumy: University Book.

Mikitas, M.A. (2013). Mechanism of organization potential influence on industrial enterprise sustainable development. PhD thesis: 08.00.05. Saint Petersburg.

Pechatkina, E.Yu., \& Menshikova, N.V. (2011). Reflexive management of corporate enterprise sustainable development. Bulletin of Chelyabinsk State University, 36, 150-170.

Petrushinova, V.Ts. (2014). Sustainable development of rural territories on the base of agricultural tourism. PhD thesis: 08.00.05. UlanUde.

Rio Declaration on Environment and Development: Adopted by UNO Conference on Environment and Development, Rio-de-Janeiro, June 3-14, 1992. [Online] Available: http://www.un.org/ru/documents/decl_conv/declarations/riodecl.shtml. (February 20, 2015).

Shestakov, A.B. (2009). Mechanism of industrial enterprise sustainable development planning. PhD thesis: 08.00.05. Moscow.

Shubina, K.S. (2011). Assessment of sustainability and conditions of industrial enterprise sustainable development. PhD thesis: 08.00.05. Khabarovsk.

Terentyev, D.V. (2005). Formation of management strategy for industrial enterprise sustainable development and mechanisms of its realization. PhD thesis: 08.00.05. Orel.

Towards a Green Economy: Pathways to Sustainable Development and Poverty Eradication. Summary Address for Representatives of Power-Holding Structures. UNEP, 2011. [Online] Available: http://www.un.org/ru/development/sustainable/ger_synthesis.pdf. (February 23, 2015).

UNO and Sustainable Development: National Strategies of Sustainable Development. [Online] Available: http://www.un.org/rul development/sustainable/nationalinfo.shtml. (February 21, 2015).

Vasikova, A.F. (2011). Some aspects of sustainable development formation as of balanced development of society and nature. Bulletin of NGSU, 2. [Online] Available: http://cyberleninka.ru/article/n/nekotorye-aspekty-formirovaniya-ustoychivogo-razvitiya-kaksbalansirovannogo-razvitiya-obschestva-i-prirody. (February 1, 2015).

Zinger, O.A. (2010). Formation of industrial enterprise sustainable development strategy. PhD thesis: 08.00.05. Penza. 